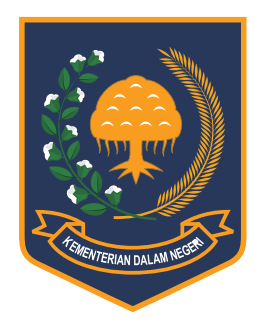

JURNAL BINA PRAJA

e-ISSN: 2503-3360 | p-ISSN: 2085-4323

Accreditation Number

21/E/KPT/2018

http://jurnal.kemendagri.go.id/index.php/jbp/index

\title{
FiSCAL DECENTRALIZATION DILEMA IN INDONESIA: BETWEEN CORRUPTION ACCOUNTABILITY AND PRobability at Local LEVELS
}

\author{
Agus Fatoni ${ }^{1, *}$ \\ ${ }^{1}$ Research and Development Agency, Ministry of Home Affairs \\ Republic of Indonesia \\ Jl. Kramat Raya No. 132, Senen, Jakarta 10450
}

Received: 7 April 2020; Accepted: 1 May 2020; Published online: 28 May 2020

DOI: $10.21787 / j b p .12 .2020 .101-110$

\begin{abstract}
Decentralization in Indonesia is an unfinished reform and to date, its implementation has not been maximized especially fiscal decentralization. This study aims to investigate the dilemma of fiscal decentralization in Indonesia, between accountability and the probability of corruption at the local level. Data collection in this research is in the form of documentation study to collect secondary data. Secondary data, this study will rely on documentary analysis of official documents from government, NGOs and news items from the media. For data analysis, the study will run analysis processes such as coding, combining emerging codes into themes, verifying themes through theory and follow-up interviews, and drawing conclusions. Whereas the validity mechanism applies member checks, triangulation, multiple sources of data, and looking for counterexamples. This research empirically found that the implementation of fiscal decentralization in Indonesia not only had a positive impact on the financial accountability of local governments but also had a positive impact on the occurrence of corruption in local governments. This means, fiscal decentralization is like two sides of a coin, on the one hand, it is able to increase the financial accountability of local governments, but on the other hand the greater the balance of funds provided by the central government to the regions, the higher the probability of corruption in local governments. Therefore, the supervision of the implementation of fiscal decentralization in order to create good financial governance and minimize corruption in the local government body in Indonesia.
\end{abstract}

Keywords: Regional Autonomy, Regional Government, Fiscal Decentralization, Budget Corruption.

\section{INTRODUCTION}

The administration of regional government in Indonesia has experienced a sharp leap from centralization to decentralization, namely the transfer of power from the central government to local governments. The transfer of power to local governments aims to improve the stability of the democratic system, increase effectiveness and efficiency, stimulate the formation of local and national economic development bases, increase government transparency and increase community involvement in decision making (Isufaj, 2014).

The implementation of decentralization is expected not only to reduce the burden of duties and responsibilities of the central government but also to increase the number and quality of public services so that the welfare of the community can also increase (Baskaran, 2011; Kyriacou \& Roca-Sagalés, 2011; Sari \& Arza, 2019).

Decentralization is defined as a process of political, fiscal devolution, and decision making from the central government to regional governments (Isufaj, 2014; K. Simanjuntak, 2015; Syahruddin, n.d.). Fiscal decentralization is a core component of decentralization because, in order to exercise the authority that has been transferred, adequate sources of financing are needed (Isufaj, 2014). Without being followed by fiscal and political decentralization, administrative decentralization will not be valid (Gideon, 2001).

Fiscal decentralization is defined as the transfer of expenditure and income functions from the central

\footnotetext{
* Corresponding Author

Phone : +62811 1800585

Email : afatonikemendagri@gmail.com
} 
government to regional governments (Abdullah, 2015; Saragih, 2003; Syahruddin, n.d.). The existence of fiscal decentralization has a clear and strict separation in financial matters between the central government and regional governments.

Fiscal decentralization produces economic benefits for the country, such as increased growth rates, increased effectiveness and efficiency in resource management, and increased community participation in decision making (Liu, 2007; Syahruddin, n.d.).

Fiscal decentralization is also able to improve the quality of decision making by using local information, increasing accountability and increasing the ability to respond to local needs and conditions (Fontanella \& Rossieta, 2014; Giannoni \& Hitiris, 2002; Mudhofar \& Tahar, 2016; Purbasari \& Bawono, 2017; Yudha et al., 2016). Also, local governments are more responsive to their citizens than the central government so that decisions taken reflect more the needs and desires of the people so that their participation will also be greater (Isufaj, 2014; Mills, 1994).

In the Indonesian context, decentralization is marked by changes in the pattern of relations between the central and regional governments after the enactment of Law No. 22 of 1999 concerning Regional Government which was later refined to become Law No. 32 of 2004 concerning Regional Government and Law No. 33 of 2004 concerning Financial balance between the central and regional governments, and the latest is Law No. 23 of 2014 concerning Regional Government. The implementation of regional autonomy raises various problems because regions have different capacities and capabilities in terms of finance, infrastructure availability, and human resource capacity (Syahruddin, n.d.).

The implementation of regional autonomy, which is followed by the transfer of power and authority to manage some central government affairs to the regions, requires reform of government management on various aspects, including regional financial management (Carnegie \& West, 2005). With fiscal decentralization, there was a significant flow of funds from the central government to regional governments (Syahruddin, n.d.). Ideally, fiscal decentralization can improve efficiency, effectiveness, transparency, and accountability in government financial management (Isufaj, 2014). This condition is proven in some areas where fiscal decentralization increases economic growth, increases public participation in decision making, and improves the quality of public services (Liu, 2007). However, in some countries, it is found that the level of corruption is getting higher after the implementation of fiscal decentralization (Isufaj, 2014).
Crook \& Sverrisson (2001), Wu (2005), Chêne (2007), Liu (2007), and Maria et al. (2019), in his research, found that fiscal decentralization has a positive impact on increasing corruption in the regions, rather than producing improvements in the quality of public services. Fiscal decentralization without support supported by Good Public Governance mechanism will only produce a corrupt government. In contrast, the findings of Fisman \& Gatti (2002), in a cross-country study, found that fiscal decentralization is negatively related to corruption, meaning that fiscal decentralization has led to the creation of good governance. Good governance in the government sector is vital to increase accountability, participation, transparency, and public performance in government affairs (Addink, 2019; Kapucu, 2009).

This proves that the implementation of decentralization in Indonesia has an ambiguous impact. On the one hand, the implementation of decentralization makes regions more responsive and flexible in providing public services, but on the other hand, the application of this policy makes corrupt practices occur not only in the central government but also spread to local governments (Akbar, 2013; Anan, 2012; Hartanto \& Probohudono, 2013; Hill, 2012; Holtzappel \& Ramstedt, 2009; Kuncoro, 2006; Maria et al., 2019; Puspasari \& Suwardi, 2016; Rinaldi et al., 2007; Syarif, 2017; Utami, 2018).

Decentralization has led to corrupt practices in local government mostly carried out by local officials (Valsecchi, 2013). This is evidenced by the rampant corruption cases that have befallen regional head and legislative leaders. From 2004 to 2019, 124 regional heads in Indonesia were entangled in corruption (Jayani, 2019). Finally, there were 41 of the total 45 members of the Malang City DPRD who were suspected in corruption cases by the Corruption Eradication Commission (KPK) of the Republic of Indonesia (Juwono \& Mayasari, 2019).

Massive corruption still occurs in Indonesia, despite significant improvements to changes in regulations, law enforcement, and regional government autonomy that have been implemented after institutional reforms after the economic damage and political crisis in the late 1990s, which pushed the country to become more democratic, decentralized, and deregulated (Henderson \& Kuncoro, 2011; Mursitama, 2007).

Changes in the political structure and multiparty system have increased the number of corruption cases involving local political figures in the executive and legislative branches because the local parliamentary control mechanism is not functioning correctly. One phenomenon, prevalent in almost all regions in Indonesia as a result of sizeable regional autonomy, 
is the "small king," in which local political figures have the political power to play a dominant role in all aspects of life and also create corrupt bureaucracies (Arifin et al., 2015).

Not only in Indonesia, the results of research on the relationship between fiscal decentralization and corruption in various countries also provide mixed findings. This encourages research to re-examine the effects of fiscal decentralization on corruption in different contexts. So far, decentralization research in Indonesia has only focused on discussing political, administrative, and economic decentralization (Liu, 2007; Muqoyyidin, 2013; Tirtosudarmo, 2008). However, research on fiscal decentralization is still a few. Some previous research has tried to link fiscal decentralization and corruption with quantitative approvals, but the results are still inconclusive because fiscal decentralization is a complex multidimensional construct (Elsye, 2014; Isufaj, 2014; Rinaldi et al., 2007; Saputra, 2012). Thus, it is necessary to re-analyze the relationship between fiscal decentralization with accountability and the probability of corruption at the local (local government) level with a different method, namely a qualitative approach.

Investigating the relationship between fiscal decentralization and elite corruption opportunities in local government is essential and exciting for several reasons. First, fiscal decentralization relates to the flow of funds belonging to the community, which must be accounted for by their use and management returned to the public as the ultimate owner of the government (Haryanto, 2017; Mimba et al., 2007; Syahruddin, n.d.). Second, the effectiveness and efficiency of decentralization as a whole are greatly influenced by the welfare of the people in the region (Haug, 2007). Therefore, this research aims to investigate the dilemma of fiscal decentralization in Indonesia between accountability and opportunities for corruption at the local level.

\section{METHOD}

This research uses a qualitative method that aims to understand the objects studied in-depth (Creswell, 2009; Patton, 1990; Taylor et al., 2015; Yin, 2014). Data collection in this research is in the form of a documentation study to collect secondary data. Secondary data, this research will rely on the documentary analysis of official documents from the government, NGOs, and news from the media.

For data analysis, this research will carry out analysis processes such as coding, combining code that appears into the theme, verifying the theme through theory and follow-up interviews, and drawing conclusions (Boeije, 2009; Creswell, 2009). While the validity mechanism applies to member checking, triangulation, many data sources, and looking for examples of counterpoints (Merriam, 1998).

\section{RESULTS AND DISCUSSION}

\section{A. Fiscal Decentralization and Regional Financial Accountability}

The implementation of fiscal decentralization in the Reformation era officially began on January 1,2001 . The process began with the enactment of Law No. 22 of 1999 concerning Regional Government and Law No. 25 of 1999 concerning Financial Balance Between Central and Regional Governments (PKPD). Until now, the two regulations have been revised several times until the latest Act No. 23 of 2014 concerning Regional Government and Act No. 33 of 2004 concerning Financial Balance Between Central Government and Regional Governments.

Initially, the implementation of fiscal decentralization in Indonesia was aimed at creating aspects of independence in the regions. As a consequence, the regions then received the delegation of authority in all fields, except authority in the fields of foreign policy, defense, security, justice, monetary and fiscal, as well as religious matters. The delegation of authority was also followed by the surrender of funding sources in the form of handing over-taxation bases and funding assistance through the Transfer to Regions mechanism under the principle of money follows function. The existence of the Transfer to Regional mechanism is based on the consideration of reducing inequality that may occur both between regions (horizontal imbalances) and between central and regional governments (vertical imbalances).

Ideally, fiscal decentralization can improve efficiency, effectiveness, transparency, and accountability in government financial management. Accountability is one of the principles of good governance of great concern today. Public accountability for local governments includes providing information on government financial activities and performance to parties with interest in financial statements. The realization of accountability is the main objective of public sector reform, especially financial reform. The government is responsible to the community directly or indirectly because the source of funds used by the government in running the government comes from the community.

Public sector accounting cannot escape from the influence of the tendency to strengthen the demands of public sector accountability. Public sector accounting that has the final results of financial statements is demanded to be a tool for planning and controlling the public sector that is the government 
effectively and efficiently and facilitates the creation of accountability, which is part of the embodiment of good governance.

Accountability of government financial statements is evidence of whether or not the government meets existing standards. As an obligation which strengthens the accountability of a financial report, the report is accountable not only to the internal organization but also to the external organization. The internal organization that is most competent in the flow of an implementation of accountability in the regions is the DPRD (Regional People's Representative Council). In contrast, the external organization can refer to an official institution that is independent, namely the BPK (Supreme Audit Agency) representative in the region.

Accountability, in addition to being part of good governance and related to the objectives of financial statements, also affects the need for Government Accounting Standards, which are guidelines for the presentation of financial statements. The setting of Government Accounting Standards in Indonesia in 2005 was a significant leap in the regulation of Indonesia's financial history because it provided a new working foundation for the bureaucratic apparatus to regulate government financial affairs.

Government Accounting Standards provide criteria in assessing the information presented, whether it is following generally accepted accounting principles or not. It is considered capable of encouraging the realization of good governance in the field of government finance because the existence of mutually agreed and legal standards can ensure consistency in financial reporting. The absence of adequate accounting standards will lead to negative implications in the form of low objectivity of the information presented, inconsistencies in financial reporting, and difficulties in auditing so that accountability is difficult to define.

Transparent financial management is a demand of stakeholders in order to realize the prosperity of a just society. As a regional financial manager, the Regional Head has asked for the mandate to manage regional finances to the public in the general election. Therefore, transparency in financial management is an absolute demand for regional financial managers.

Transparent financial management is a demand of stakeholders in order to realize the prosperity of a just society. The Regional Head, as a regional financial manager, has asked for the mandate to manage regional finances to the public in the general election. Therefore, transparency in financial management is an absolute demand for regional financial managers.

Transparency, namely openness in government, environmental, economic, and social management, where the public can access information relating to financial management carried out by the government on the use of public funds. Government Accounting Standards (SAP) explain that transparency implies "providing financial information that is open and honest to the community based on the consideration that the public has the right to openly and comprehensively acknowledge the responsibility of the local government in managing the resources entrusted to him and his adherence to regulations of the Constitution."

Transparency in regional financial management, as stated by Djalil (2014), will provide four essential benefits. First, it can detect irregularities in the management of regional finances in the form of fraud, non-compliance, management of laws and regulations, and non-compliance to minimize regional losses. Second, the weaknesses and strengths of policies can be identified earlier so that improvements can be made immediately so that the achievement of organizational goals can be achieved. Third, increase the confidence of stakeholders, especially the public, so that their adherence to local government regulations can be increased. Finally, creating a conducive investment climate so that investors are interested in investing in the region so that it can revive the economy of the local community.

At present, the need for accountability is increasing because of the high demands of stakeholders to realize good governance. The conditions for the creation of good governance are transparency in the implementation of participatory and accountable governance for the community.

The issuance of the Law package, namely Law No. 17 of 2003 concerning State Finance and Law No. 1 of 2004 concerning the State Treasury and Law No. 33 of 2004 concerning Central and Regional Financial Balances, brought about a fairly fundamental change in regional financial governance. Local governments are required to be more transparent and accountable in managing and accounting for regional money and goods.

The regional government is also required to hold regional financial management accountable by presenting regional financial reports as a form of accountability for the implementation of regional finances. The responsibility of the regional government is to prepare more transparent and accountable financial statements that can describe revenue and expenditure as well as regional cash flows during one period and describe the financial position at the reporting date.

The preparation of financial statements is a form of transparency needs that is a requirement that regional financial management can be said to be accountable. The form is in the form of openness of the regional government to the activity of managing 
public resources. Transparency of information, primarily financial and fiscal information, must be carried out in a form that is relevant and easily understood.

Transparency is providing open and honest financial information to the public. The basis for consideration is that the public has the right to know openly and comprehensively the responsibility of the government in managing the resources entrusted to it and its compliance with laws and regulations (Government Regulation No. 71 of 2010 concerning Government Accounting Systems). Transparency can be measured at least using three indicators. First, a mechanism that guarantees a system of openness and standardization of all public service processes. Second, a mechanism that facilitates public questions about various policies and public services as well as processes within the public sector. Third, the mechanism that facilitates reporting and irregularities in the actions of public officials in public service activities.

One indicator of financial statements that are said to be transparent is BPK's opinion on the Regional Government Financial Reports (LKPD). If the Fair Opinion without Exception (WTP) can be said that the financial statements are transparent, on the contrary, if the WTP does not yet mean it is not transparent. The increase in the percentage of PAP opinion generally reflects an improvement in financial accountability by regional governments in presenting financial reports following applicable accounting principles and standards. The tendency towards positive is shown by local government entities.

The number and percentage of WTP opinion recipients from the BPK have increased from year to year. Based on BPK's first semester 2019 examination of 504 Regional Government Financial Statements (LKPD), the percentage of those who received WTP opinion in LKPD in 2018 increased rapidly from 29.7\% in LKPD in 2017 to 49.8\% (251 LKPD) in 2018 LKPD. Increase This was mainly due to the improved quality of LKPD from previously obtaining a Fair with Exception (WDP) opinion to WTP. Still referring to the comparison in the same two years, the percentage of LKPD who obtained WDP opinion (230 LKPD) fell from $59.35 \%$ to $45.64 \%$. The rapid increase in the percentage of WTP opinion due to the increase in opinion from LKPD, which previously obtained WDP opinion, generally illustrates the improvement achieved by local government entities. Especially in presenting a reasonable financial statement following applicable principles.

The implementation of regional autonomy and fiscal decentralization has brought significant developments in the financial management of the regional government in Indonesia. The change includes centralization to decentralization, from a traditional budgeting system to a performance-based budgeting system, from a vertical accountability system to a horizontal accountability system. At present regional financial management and accountability refer to Law No. 17 of 2003. These arrangements include the preparation of performance-based Regional Revenue and Expenditure Budgets (APBD) and comprehensive financial reports as a form of accountability that must be examined by the Supreme Audit Agency (BPK).

If we consider the existing set of rules, it can be seen that the existing policy is demanding the implementation of government functions, specifically public financial management, to be more transparent and accountable. This is one of the critical lessons from the experience of government management in the New Order era. The next important thing is to ensure the realization of transparency and accountability in the management of regional finances with established policies.

Through government financial reports, the information needed by various parties such as the public, representatives of the people, supervisory institutions, and inspection institutions, those who give or play a role in the process of donations, investments, and loans, as well as the government itself for decision making will be presented comprehensively. The need for financial information at this time, especially among the community is increasingly significant. The information presented by the public sector must be able to make useful contributions, not just fulfilling obligations, but must be compliant and following the provisions or regulations that have been set.

Financial reporting from all local government entities must be done in a consistent, timely, and transparent manner. If this can be done, it indicates that the local government has held accountability (Steccolini, 2003). A similar opinion was expressed by Ryan et al. (2002), which states that there are two generally accepted goals of annual reporting of the public sector, namely accountability and decision usefulness.

Concerning the presentation of regional financial reports, there have been fundamental reforms since the enactment of Government Regulation No. 58 of 2005 concerning Regional Financial Management. The Government Regulation requires regional heads to prepare financial reports, namely: Budget Realization Reports, Regional Balance Sheets, Cash Flow Reports, and Notes to Financial Statements. However, efforts to improve regional financial reporting are not yet fully implemented by the regional government. In reality, local governments cannot immediately compile financial reports, especially the Balance Sheet. The 
fact that local governments do not have a balance sheet is due, among other things, to the fact that the existing system and reporting are not conducive to this direction (Halim, 2001). Another problem is the publication of financial reports by local governments (through newspapers, the internet, or in other ways) does not seem to be an everyday thing.

According to Jonas \& Blanchet (2000), the inability of financial statements to carry out accountability is not only because the annual report does not contain all relevant information needed by users, but also because the report cannot be directly available and accessible to potential users. As a consequence, the presence of incomplete and inaccessible financial statements can reduce the quality of transparency and accountability in regional finances.

Several previous studies have proven that fiscal decentralization can provide economic benefits for a country. Syahruddin (n.d.) found that fiscal decentralization can increase a country's economic growth. The increase in economic growth is probably due to fiscal decentralization, which provides an opportunity for regions to build independence in obtaining funding. A similar sentiment was also expressed by Sasana (2009) and Huda \& Sasana (2013), that in Indonesia, fiscal decentralization increases the efficiency of public services and economic growth. Liu (2007) found that fiscal decentralization improved the quality of public services. Fiscal decentralization also resulted in the provision of public goods under the specifications needed by the community.

From various empirical evidence in the previous literature, it can be concluded that the independence of funding through fiscal decentralization has a positive impact on financial accountability. Some literature reveals that fiscal decentralization increases the efficiency, effectiveness, and accountability of public services and reduces the level of corruption. Halim (2001) explains the main characteristic of a region that has implemented decentralization well is that the region has the ability and authority to explore financial resources, manage and use it to finance governance, and reduce dependence on the central government. Ideally, with fiscal decentralization that is complemented by a set of rules on management and adequate regional financial audits, the independence of regional funding through fiscal decentralization can improve the accountability and management of local government financial reporting.

\section{B. Fiscal Decentralization and Local Government Corruption}

Fiscal decentralization gives regions the freedom to develop their work programs and reallocate budgets according to the needs and capacities of regions aimed at improving regional economic economies and reducing disparities between regions. Local governments respond to decentralization in two ways: (1) increasing revenue (revenue side) through intensification and expansion of taxes, regional levies and utilizing resources that have not been optimal through revenue sharing; and (2) increasing the effectiveness/quality of the expenditure side to stimulate the business world through the development of a better business climate.

Most cities and regencies in Indonesia respond inappropriately to fiscal decentralization by boosting the increase in PAD through taxes and fees without being offset by increasing APBD expenditure effectiveness. This method can adversely affect regional trade and investment activities, which inturn will reduce regional income and employment opportunities.

In the course of the implementation of fiscal decentralization in Indonesia incised a good story even though not a few also had terrible records, such as the rise of corrupt practices. Corruption is one of the biggest problems faced by the Indonesian people to date. Even corruption in Indonesia has been regarded as endemic, systemic, and widespread. Ideally, fiscal decentralization can improve efficiency, effectiveness, transparency, and accountability in government financial management. However, in some countries, the level of corruption is getting higher after the implementation of fiscal decentralization.

The issue of decentralization and corruption itself has indeed attracted the attention of many experts. On the one hand, there are those who believe that decentralization can have a positive impact on minimizing corrupt practices, but there are also those who say that fiscal decentralization is remedial for corruption.

In the era of President Joko Widodo's administration, the budget for central government transfers to the regions has increased every year. In 2014 TKDD (Regional Transfer and Village Fund) was Rp573.7 trillion, up to Rp832.3 trillion in 2019, or an increase of $45.1 \%$ over five years. For the first time, in 2016, the TKDD was higher (Rp776.3T) than the expenditure of the Ministry and Institutions (Rp767.8T). The following is the development of TKDD (Transfer to Regions and Village Funds) in the 2014-2019 period in Table 1.

The relatively significant increase in transfer funds each year has improved the performance of 
Table 1.

Transfer to Regions and Village Funds Growth Chart 2014-2019

\begin{tabular}{cc} 
Year & $\begin{array}{c}\text { TKDD } \\
\text { (Trillion) }\end{array}$ \\
\hline 2014 & Rp573.7 \\
\hline 2015 & Rp664.6 \\
\hline 2016 & Rp776.3 \\
\hline 2018 & Rp759.2 \\
\hline 2019 & Rp766.2 \\
\hline
\end{tabular}

Source: Directorate General of Fiscal Balance (analyzed, 2019)

public services, which is reflected in the improvement in public service indicators, including

1. the gap index between regions improved from 2014-2019, from 0.759 to 0.668 ,

2 . household access to sanitation from $61.1 \%$ to $67.9 \%$,

3. and the number of deliveries handled rose from $87.1 \%$ to $93.3 \%$,

4. underdeveloped villages decreased by 6,518 villages, exceeding the target of 5,000 villages in the 2015-2019 RPJMN,

5. rural infrastructure development increased from $39.21 \%$ in 2014 to $44.63 \%$ (DJPK, 2019).

In addition to the positive side, the negative note is the rampant cases of corruption of regional heads and corruption in congregations in various regions involving the executive. Regional heads or executive officials involved in legal issues due to corruption are very alarming. In the 2014-2019 period, there were 105 corruption cases involving high-ranking regional officials in 22 provinces. Of the 105 cases, 90 of them involved regents and mayors, and 15 other cases involved governors (Rini, 2019). Decentralization causes corruption practices in local governments, mostly carried out by local officials (Valsecchi, 2013).

The following 22 provinces and the number of corruption cases: Aceh 4 cases, Bengkulu 3 cases, West Java 16 cases, Central Java 8 cases, East Java 13 cases, South Kalimantan 1 case, Central Kalimantan 1 case, East Kalimantan 5 cases, North Maluku 3 cases, NTB 3 cases, NTT 2 cases, Papua 5 cases, Riau 5 cases, Riau Islands 2 cases, South Sulawesi 2 cases, Central Sulawesi 1 case, Southeast Sulawesi 5 cases, North Sulawesi 3 cases, South Sulawesi 6 cases, North Sumatra 12 cases, Jambi 1 case, and Lampung 3 cases (Rini, 2019).
The data shows that there have been many cases of corruption by regional heads during the implementation of fiscal decentralization in Indonesia. This finding is in line with the findings of Crook \& Sverrisson (2001), Wu (2005), Chêne (2007), Liu (2007), and Maria et al. (2019), which also found that fiscal decentralization had a positive effect on increasing corruption in the regions, not resulting in an improvement in the quality of public services. Fiscal decentralization without support supported by Good Public Governance mechanism will only produce a corrupt government.

Fiscal decentralization in Indonesia is like two sides of a coin. On the one hand, it can improve public services, but on the other hand, the higher the balance of funds provided by the central government to the regions, the higher the probability of corruption in local governments. This proves that the implementation of decentralization in Indonesia has an ambiguous impact. On the one hand, the implementation of decentralization makes regions more responsive and flexible in providing public services, but on the other hand, the application of this policy makes corrupt practices occur not only in the central government but also spread to local governments (Akbar, 2013; Anan, 2012; Hartanto \& Probohudono, 2013; Hill, 2012; Holtzappel \& Ramstedt, 2009; Kuncoro, 2006; Maria et al., 2019; Puspasari \& Suwardi, 2016; Rinaldi et al., 2007; Syarif, 2017; Utami, 2018).

\section{ConClusion}

This research empirically found that the implementation of fiscal decentralization in Indonesia not only had a positive impact on the financial accountability of local governments, but also had a positive impact on the occurrence of corruption in local governments. This means, fiscal decentralization is like two sides of a coin, on the one hand, it can increase the financial accountability of local governments, but on the other hand the higher the balance of funds provided by the central government to the regions, the higher the probability of corruption in local governments. Therefore, the supervision of the implementation of fiscal decentralization in order to create sound financial governance and minimize corruption in the local government body in Indonesia. The findings of this research are in line with the findings of previous research that the implementation of fiscal decentralization can improve regional financial accountability, but new findings from this study that fiscal decentralization also increases cases of corruption in the regions if not adequately monitored. 


\section{ACKNOWLEDGMENT}

The author thanks the Dean of the Faculty of Government Management of the Institute of Governance of Home Affairs (IPDN) for supporting this research. The author also thanks Irwandi, who collected field research data.

\section{REFERENCES}

Abdullah, H. (2015). Realokasi Kebijakan Fiskal: Implikasi Peningkatan Human Capital dan Pembangunan Infrastruktur terhadap Pertumbuhan Ekonomi dan Kesejahteraan Masyarakat. Jurnal Bina Praja: Journal of Home Affairs Governance, 6(2), 117-128. https://doi. org/10.21787/jbp.06.2014.117-128

Addink, H. (2019). Good Governance. Oxford University Press. https://doi.org/10.1093/ oso/9780198841159.001.0001

Akbar, M. R. H. (2013). Analisis Determinan Ekonomi Korupsi di Era Desentralisasi pada 12 Ibukota Provinsi Indonesia. Jurnal Ilmiah Mahasiswa FEB, 1(2). https://jimfeb.ub.ac.id/index.php/ jimfeb/article/view/612

Anan, E. (2012). Desentralisasi Fiskal dan Tingkat Korupsi di Indonesia. EBBANK, 3(2), 371-382. http://ebbank.stiebbank.ac.id/index.php/ EBBANK/article/view/50

Arifin, T., Trinugroho, I., Prabowo, M. A., Sutaryo, S., \& Muhtar, M. (2015). Local governance and corruption: Evidence from Indonesia. Corporate Ownership and Control,12(4), 194-199. https:// doi.org/10.22495/cocv12i4c1p3

Baskaran, T. (2011). Fiscal decentralization, ideology, and the size of the public sector. European Journal of Political Economy, 27(3), 485-506. https: // doi.org/10.1016/j.ejpoleco.2011.03.003

Boeije, H. R. (2009). Analysis in Qualitative Research. SAGE.

Carnegie, G. D., \& West, B. P. (2005). Making accounting accountable in the public sector. Critical Perspectives on Accounting, 16(7), 905-928. https://doi.org/10.1016/j.cpa.2004.01.002

Chêne, M. (2007). Corruption and Decentralisation in Afghanistan. In U4 Expert Answer. U4 Anti-CorruptionResource Centre. https:// www.u4.no/publications / corruption-anddecentralisation-in-afghanistan

Creswell, J. W. (2009). Research Design: Qualitative, Quantitative, and Mixed Methods Approaches (3rd ed.). SAGE Publications.

Crook, R. C., \& Sverrisson, A. S. (2001). Decentralisation and Poverty-Alleviation in Developing Countries: A Comparative Analysis or, is West Bengal Unique? In IDS Working Paper Series (130). https://opendocs.ids.ac.uk/opendocs/ handle/20.500.12413/3904

Djalil, R. (2014). Akuntabilitas Keuangan Daerah: Implementasi Pasca Reformasi. RMBooks.

Elsye, R. (2014). Implementasi Kebijakan Desentralisasi Fiskal di Provinsi Sumatera Selatan. Sosiohumaniora, 16(2), 171-183. https://doi.org/10.24198/sosiohumaniora. v16i2.5730

Fisman, R., \& Gatti, R. (2002). Decentralization and corruption: evidence across countries. Journal of Public Economics, 83(3), 325-345. https://doi. org/10.1016/S0047-2727(00)00158-4

Fontanella, A., \& Rossieta, H. (2014). Pengaruh Desentralisasi Fiskal dan Kinerja Terhadap Akuntabilitas Pelaporan Keuangan Pemerintah di Indonesia. Simposium Nasional Akuntansi 17.

Giannoni, M., \& Hitiris, T. (2002). The regional impact of health care expenditure: the case of Italy. Applied Economics, 34(14), 1829-1836. https:// doi.org/10.1080/00036840210126809

Gideon, J. (2001). The decentralization of primary health care delivery in Chile. Public Administration and Development, 21(3), 223231. https://doi.org/10.1002/pad.175

Halim, A. (2001). Manajemen Keuangan Daerah: Bunga Rampai. UPP AMP YKPN.

Hartanto, R., \& Probohudono, A. N. (2013). Desentralisasi Fiskal, Karakteristik Pemerintah Daerah dan Tingkat Korupsi Pemerintah Daerah pada Tahun 2008 dan 2010. Proceeding Simposium Nasional Akuntansi XVI Manado.

Haryanto, J. (2017). Comparative Analysis of Financial Performance in Fiscal Decentralization Era Among Natural and Non-Natural Resources Region. Jurnal Bina Praja. https://doi. org/10.21787/jbp.09.2017.171-184

Haug, M. (2007). Kemiskinan dan desentralisasi di Kutai Barat: dampak otonomi daerah terhadap kesejahteraan Dayak Benuaq. In CIFOR. Center for International Forestry Research (CIFOR). https://doi.org/10.17528/cifor/002359

Henderson, J. V., \& Kuncoro, A. (2011). Corruption and local democratization in Indonesia: The role of Islamic parties. Journal of Development Economics, 94(2), 164-180. https://doi. org/10.1016/j.jdeveco.2010.01.007

Hill, H. (2012). Corruption and development: The Indonesian experience. In S. Khoman (Ed.), A Scholar for All: Essays in Honour of Medhi Krongkaew (pp. 150-164). Thammasat University Press.

Holtzappel, C. J. G., \& Ramstedt, M. (Eds.). (2009). Decentralization and Regional Autonomy in Indonesia: Implementation and Challenges. ISEAS-Yusof Ishak Institute. https://wwW. cambridge.org/core/books/decentralization- 
and-regional-autonomy-in-indonesia/389B9E 1C406C3C9DABF80A02AD4348C7

Huda, N. A., \& Sasana, H. (2013). Analisis Dampak Desentralisasi Fiskal Terhadap Outcomes Pelayanan Publik Bidang Pendidikan (Studi Kasus: Provinsi DKI Jakarta). Diponegoro Journal of Economics, 2(1), 1-13. https://ejournal3. undip.ac.id/index.php/jme/article/view/1965

Isufaj, M. (2014). Decentralization and the Increased Autonomy in Local Governments. Procedia Social and Behavioral Sciences, 109, 459-463. https://doi.org/10.1016/j.sbspro.2013.12.490

Jayani, D. H. (2019, July 13). Sejak 2004 hingga 2019, Terdapat 124 Kepala Daerah Terjerat Korupsi (H. Widowati (Ed.)). Databoks.Katadata. Co.Id. https://databoks.katadata.co.id/ datapublish/2019/07/13/sejak-2004-hingga2019-terdapat-124-kepala-daerah-terjeratkorupsi

Jonas, G. J., \& Blanchet, J. (2000). Assessing Quality of Financial Reporting. Accounting Horizons, 14(3), 353-363. https://doi.org/10.2308/ acch.2000.14.3.353

Juwono, V., \& Mayasari, I. (2019, March 14). Pola Korupsi Pemerintah Daerah dan Pimpinan Transformasional. Kpk.Go.Id. https://www. kpk.go.id/id/berita/publik-bicara/782-polakorupsi-pemerintah-daerah-dan-pimpinantransformasional

Kapucu, N. (2009). New Public Management and Governance Perspectives in Understanding Public Management. Public Administration Review, 69(6), 1187-1190. https://doi. org/10.1111/j.1540-6210.2009.02078.x

Kuncoro, A. (2006). Decentralization and Corruption in Indonesia: Manufacturing Firms Survival under Decentralization. In The International Centre for the Study of East Asian Development (2006-25).

Kyriacou, A. P., \& Roca-Sagalés, O. (2011). Fiscal decentralization and government quality in the OECD. Economics Letters, 111(3), 191-193. https://doi.org/10.1016/j.econlet.2011.02.019

Liu, C. (2007). What Type of Fiscal Decentralization System has Better Performance? University of Maryland.

Maria, E., Halim, A., Suwardi, E., \& Miharjo, S. (2019). Desentralisasi fiskal dan probabilitas terjadinya korupsi: Sebuah bukti empiris dari Indonesia. Jurnal Ekonomi Dan Bisnis, 22(1), 1-22. https: // doi.org/10.24914/jeb.v22i1.2036

Merriam, S. B. (1998). Qualitative Research and Case Study Applications in Education: Revised and Expanded from Case Study Research in Education (2nd ed.). Wiley.
Mills, A. (1994). Decentralization and accountability in the health sector from an international perspective: What are the choices? Public Administration and Development, 14(3), 281292.https://doi.org/10.1002/pad.4230140305

Mimba, N. P. S., Helden, G., \& Tillema, S. (2007). Public Sector Performance Measurement in Developing Countries: A Literature Review and Research Agenda. Journal of Accounting and Organizational Change, 3(3), 192-208.

Mudhofar, K., \& Tahar, A. (2016). Pengaruh Desentralisasi Fiskal dan Kinerja Terhadap Akuntabilitas Pelaporan Keuangan Pemerintah Daerah di Indonesia: Efek Moderasi dari Kinerja. Jurnal Akuntansi Dan Investasi, 17(2), 176-185. https://doi.org/10.18196/jai.2016.0053.176185

Muqoyyidin, A. W. (2013). Pemekaran Wilayah dan Otonomi Daerah Pasca Reformasi di Indonesia: Konsep, Fakta Empiris dan Rekomendasi ke Depan. Jurnal Konstitusi, 10(2), 287-309. https://jurnalkonstitusi.mkri.id/index.php/ jk/article/view/105

Mursitama, T. N. (2007). Creating relational rents: The effect of business groups on affiliated firms' performance in Indonesia. Asia Pacific Journal of Management, 23(4), 537-557. https: // doi, org/10.1007/s10490-006-9014-3

Patton, M. Q. (1990). Qualitative Evaluation and Research Methods. SAGE Publications.

Purbasari, H., \& Bawono, A. D. B. (2017). Pengaruh Desentralisasi Fiskal, Sistem Pengendalian Internal dan Kinerja Pemerintah Daerah Terhadap Akuntabilitas Laporan Keuangan. Riset Akuntansi Dan Keuangan Indonesia, 2(2), 102-108. https://doi.org/10.23917/reaksi. v2i2.4884

Puspasari, N., \& Suwardi, E. (2016). The Effect of Individual Morality and Internal Control on The Propensity to Commit Fraud: Evidence from Local Governments. Journal of Indonesian Economy and Business, 31(2), 208-219. https:// doi.org/10.22146/jieb.15291

Rinaldi, T., Purnomo, M., \& Damayanti, D. (2007). Memerangi Korupsi di Indonesia yang Terdesentralisasi: Studi Kasus Penanganan Korupsi Pemerintahan Daerah. In Justice for the Poor Project (No. 43641; 1). http:// d ocuments.worldbank.org / curated/ en /593731468040748249/Memerangikorupsi-di-Indonesia-yang-terdesentralisasistud i - kasus - penangan an - korupsipemerintahan-daerah

Rini, R. A. P. (2019, June 18). Sepanjang 2014-2019, Tercatat 105 Kasus Korupsi Libatkan Pejabat 
Tinggi Daerah, Ini Daerahnya (J. Simanjuntak (Ed.)). Tribunnews.Com. https://www. tribunnews.com/nasional/2019/06/18/ sepanjang-2014-2019-tercatat-105-kasuskorupsi-libatkan-pejabat-tinggi-daerah-inidaerahnya

Ryan, C., Stanley, T., \& Nelson, M. (2002). Accountability Disclosures by Queensland Local Government Councils: 1997-1999. Financial Accountability \& Management, 18(3), 261-289. https://doi. org/10.1111/1468-0408.00153

Saputra, B. (2012). Dampak Desentralisasi Fiskal Terhadap Korupsi di Indonesia. Jurnal Borneo Administrator, 8(3), 293-309. https://doi. org/10.24258/jba.v8i3.92

Saragih, J. P. (2003). Desentralisasi Fiskal dan Keuangan Daerah dalam Otonomi. Ghalia Indonesia.

Sari, M., \& Arza, F. I. (2019). Pengaruh Karakteristik Pemerintah Daerah Terhadap Kondisi Financial Distress Pemerintah Daerah Kabupaten dan Kota Se-Indonesia Periode 2015-2017. Wahana Riset Akuntansi, 7(1), 1425-1436. http://ejournal. unp.ac.id/index.php/wra/article/view/104566

Sasana, H. (2009). Peran Desentralisasi Fiskal Terhadap Kinerja Ekonomi di Kabupaten/ Kota Provinsi Jawa Tengah. Jurnal Ekonomi Pembangunan: Kajian Masalah Ekonomi Dan Pembangunan, 10(1), 103-124. https://doi. org/10.23917/jep.v10i1.811

Simanjuntak, K. (2015). Implementasi Kebijakan Desentralisasi Pemerintahan di Indonesia. Jurnal Bina Praja, 7(2), 111-130. https://doi. org/10.21787/JBP.07.2015.111-130

Steccolini, I. (2003). Local Government Annual Report: An Accountability Medium? SSRN Electronic Journal. https://doi.org/10.2139/ ssrn.376204

Syahruddin, H. (n.d.). Desentralisasi Fiskal: Perlu Penyempurnaan Kebijakan dan Implementasi yang Konsisten. https://docplayer.
info/46383870-Desentralisasi-fiskal-perlupenyempurnaan-kebijakan-dan-implementasiyang-konsisten.html\#show_full_text

Syarif, A. (2017). Desentralisasi Fiskal dan Korupsi: Fakta dalam Era Otonomi Daerah (Studi pada 15 Kabupaten/Kota di Indonesia) [Universitas Gadjah Mada].http://etd.repository.ugm.ac.id/ home/detail_pencarian/110315

Taylor, S. J., Bogdan, R., \& DeVault, M. (2015). Introduction to Qualitative Research Methods: A Guidebook and Resource (4th ed.). John Wiley \& Sons.

Tirtosudarmo, R. (2008). Paradigma dalam Kebijakan Desentralisasi di Indonesia: Sebuah Kritik Terhadap Dominasi Public Administration School. Jurnal Masyarakat \& Budaya, 10(1), 27-52. http://jmb.lipi.go.id/index.php/jmb/ article/view/170

Utami, I. S. (2018). Desentralisasi, Korupsi, dan Tambal Sulam Pemerintahan Daerah di Indonesia. Jurnal Pendidikan Kewarganegaraan, 5(1), 35-46. https://doi.org/10.32493/jpkn. v5i1.y2018.p35-46

Valsecchi, M. (2013). Local Elections and Corruption during Democratization: Evidence from Indonesia. https://lir.gu.se/ digitalAssets/1457/1457696_130130_mv_ corruption.pdf

Wu, X. (2005). Corporate Governance and Corruption: A Cross-Country Analysis. Governance, 18(2), 151-170. https://doi.org/10.1111/j.14680491.2005.00271.x

Yin, R. K. (2014). Case Study Research. SAGE Publications, inc.

Yudha, D. M. A. K., Wirakusuma, M. G., \& Rasmini, N. K. (2016). Pengaruh Desentralisasi Fiskal pada Pertumbuhan Ekonomi dengan Moderasi Akuntabilitas Pelaporan Keuangan. E-Jurnal Ekonomi Dan Bisnis Universitas Udayana, 5(8), 2461-2490. https://ojs.unud.ac.id/index.php/ EEB/article/view/19930 